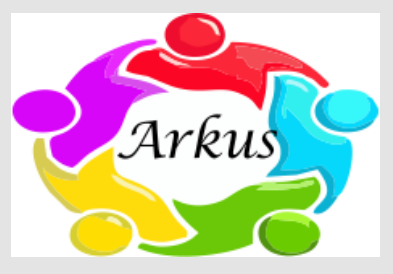

ARKUS

Journal Homepage:

https://hmpublisher.com/index.php/arkus

\title{
Effectivity of Acupressure in Low Back Pain
}

\section{Indri Seta Septadina ${ }^{*}$}

${ }^{1}$ Department of Anatomy, Faculty of Medicine, Universitas Sriwijaya, Palembang, Indonesia

\author{
A R T I C L E I N F O \\ Keywords: \\ Low back pain \\ Rotation \\ Physical therapy modalities \\ Lower extremities

\section{Corresponding author:} \\ Indri Seta Septadina \\ E-mail address: \\ indrisetaseptadina@gmail.com
}

The author has reviewed and approved the final version of the manuscript.

\begin{abstract}
A B S T R A C T
Low back pain is defined as located pain and discomfort below the costal margin and above the superior gluteal line, with related pain in the lower limb, and repeated incorrect posture of work activities that demand effort with excess of flexion, rotation, vibration on the chest and carrying weight, being chronic if its persists for three months or more. This research aimed to find out the efficacy of accupressure on Dachangshu, Shenshu, and Yaoyangquan points using pretestposttest group design by comparing the mean decrease in pain threshold, RMDQ and Test Straight Leg between control using Dingchuan and Waihuaijian points and therapy group using Shenshu, Dachangshu, and Yaoyangquan acupoints twice a day with paired $T$ test formula. The mean decreased in pain threshold VAS, RMDQ and Test Straight Leg obtained form therapy group toward 16 elderly above 45 years for 4 weeks showed that there is a significant result $(p=0,000)$. In conclusion, accupressure therapy using Dachangshu, Shenshu and Yaoyangquan can be used to treat low back pain.
\end{abstract}

https://doi.org/10.37275/arkus.v7i1.92

\section{Introduction}

Currently, technological developments are increasingly sophisticated and provide many conveniences so that most people become lazy to move or just light exercise in the surrounding space. Ultimately, the lack of movement causes muscles to become stiff and tense. Also, the behaviour of wrong posture in everyday life and occurs repeatedly, such as lifting items that immediately look down without squatting first, causing the support to lie on the lower back and causing lower back pain.

Low back pain (LBP) is pain that is felt in the lower back, pain that occurs locally or radicular or both. This pain is felt on the corner of the lower ribs to the crease of the lower buttocks, lumbar or lumbosacral region and is usually accompanied by pain towards the legs to the feet. The classification of LBP, according to a director of the Tokyo Metropolitan Geriatric Hospital is pain due to trauma, inflammation, tumours, degeneration, abdominal and psychological organs. sports and knowledge. ${ }^{1-4}$

A survey conducted by the American Osteopathic Association (AOA) in 2013 showed that in the last 30 days about $62 \%$ of respondents complained of pain in the lower back, 53\% in the neck, 38\% in the shoulders, $33 \%$ in the wrists, and $31 \%$ in the back. the top. ${ }^{1}$

Most of this pain began to be experienced in those aged the second decade, and the highest incidence 
was found in the fifth decade. The journal Low Back Pain Eight Areas of Britain in 1992 stated that the prevalence of LBP at the age of 30-60 years in Denmark reached $62 \%$, while the prevalence of LBP at the age of 30 years and overreached $75 \%$ and $54 \%$ in the Netherlands in men and women aged 20 years and over. 5,6

LBP cases can be handled using western medicine and eastern medicine. Western medicine which has a paradigm of "Illness is the enemy", which means that disease is a pathogen that must be fought. The drug Eperisone Hydrochloride can reduce pain in LBP sufferers but has side effects of stomach pain, dizziness, headache, feeling tired or inadequate and nausea.

Eastern medicine uses natural remedies from generation to generation, including massage, acupuncture, heating (moxibustion) and other therapies. Acupuncture is a treatment method by inserting a special small needle into the skin at a certain point, according to the patient's illness and the patient's body condition.7 In addition to acupuncture, LBP treatment can also use acupressure, which is pressing several times using the thumb, fingers, or using elbows where the pain is felt and at the acupuncture point. Also, acupressure is easy to emphasize blood circulation and oxygen. 8 Research conducted by the University of Maryland in 2003 showed that at Shenshu point (BL23), Qihaishu point (BL24), Dachangshu point (BL25) and Pangguangshu point (BL28) using acupuncture experienced an improvement in pain in LBP cases. This fact shows that the stimulation is beneficial for treating patients who experience Low Back Pain. Another study conducted by Southern Medical University in 2013 stated that acupuncture and acupressure therapy at the Yaoyangguan point (DU3) could reduce acute sciatica pain. ${ }^{9}$

The tendency of people who are still afraid of using needles can be overcome with acupressure therapy. Apart from being more readily accepted by society, patients are not afraid because they do not need to use needles and can apply it to themselves. Acupressure is believed to release endorphin hormones. Endorphin hormones are compounds released in the lower back of the brain, which function to make people feel comfortable and happy so that the pain they suffer can be reduced.

The Dachangshu point is a point located on the bladder meridian, which is the Shu point of the large intestine. Meanwhile, the Yaoyangguan point is the Du point, and the Shenshu point is the kidney meridian, which is the kidney Shu point which is known to improve the kidney organ. (BL23), and the Yaoyangguan point (DU3) its effectiveness is still unknown. This study was conducted to determine the effect of acupressure at the Dachangshu point (BL25), Shenshu point (BL23), and Yaoyangguan point (DU3) to treat LBP.

\section{Methods}

The type of research on the effect of acupressure therapy for Low Back Pain cases is a qualitative experimental method using a pre-post test control group design in patients aged $>45$ years. This study uses an experimental research method approach. Experimental research is research that is proven by facts or based on its science. Therefore, there is tight control of confounding variables that have not experimented. In another sense, experimental research is research that is not yet known to be true. Hence, it is necessary to take action/treatment on a research subject that can be observed for differences or impacts.

In this experimental design, there were two groups selected by purposive random sampling. Experimental research is causal research (cause and effect) which proves through a comparison between the subject's condition before being given treatment and after being given treatment.

In this study, the authors wanted to determine the effect of acupressure at the Dachangshu point 
(BL25), Shenshu point (BL23) and Yaoyangguan point (DU3) on Low Back Pain cases by performing a pretest-posttest control design. This research will be conducted 12 times of treatment in each group. Before being given the treatment, both groups were given a pretest in the form of filling out a questionnaire and a Straight leg test.

This research was conducted from June to December 2019 at the Alsya clinic, Palembang, Indonesia. The research subjects were 20 people who live in the city of Palembang with an age range of 45 - 60 years who have LBP. The minimum sample size used in unpaired numerical analytic research, two groups, is twice the size. The sample was taken by using a simple random method.

The tools and materials used in this study were gloves, masks, goniometer, and olive oil. The independent variables in this study were acupressure Dachangshu point (BL25), Shenshu point (BL23), and Yaoyangguan point (DU3) in the treatment group and Dingchuan point acupressure (EX-B1) and Waihuaijian point (EX-LE10) in the control group. The bound variables in this study were the reduction in LBP pain on RMDQ, VAS and measurement of leg degrees. This act of inspection is also known as a straight leg raising test. Patient size is uncomfortable with flexion. In the study, it was determined (classified) the degree of flexion of $30^{\circ}, 60^{\circ}, 90^{\circ}$ and more than $90^{\circ}$. The method of assessment using VAS (Visual Analog Scale) is that the patient marks himself with a pencil on a scale value that corresponds to the intensity of the pain he feels after being given an explanation from the researcher about the meaning of each scale. Determination of the VAS score is done by measuring the distance between the ends of the line that shows painlessness to the point indicated by the patient.

The Roland-Morris Disability Questionnaire (RMDQ) is a questionnaire consisting of 24 questions related to physical impairments that may be felt due to LBP. The patient will give a score on each question that will be added. The score of this assessment is 0 (no disability) to 24 (maximum disability). 8-9 The strength of this questionnaire is that it is easy for patients to understand. However, the drawback of the questionnaire is that it does not measure the patient's psychological or social problems.

\section{Results and discussion}

After the selection is made to be the subject of research with the purposive random sampling method. With the following table:

Table 1. Research subjects

\begin{tabular}{|c|c|c|c|c|}
\hline & ect & $\mathbf{N}$ & Mean+SD & P value \\
\hline \multirow{2}{*}{ Age (years) } & Treatment group & 8 & $51,875+5,540$ & \multirow{2}{*}{0,105} \\
\hline & Control group & 8 & $55,625 \pm 10,649$ & \\
\hline \multirow{2}{*}{ VAS $(\mathrm{mm})$ pretest } & Treatment group & 8 & $5,125 \pm 1,246$ & \multirow{2}{*}{0,348} \\
\hline & Control group & 8 & $5,625+1,847$ & \\
\hline \multirow{2}{*}{$\begin{array}{c}\text { RMDQ } \\
\text { (quesioner) } \\
\text { Pretest }\end{array}$} & Treatment group & 8 & $13,625+3,462$ & \multirow[b]{2}{*}{0,311} \\
\hline & Control group & 8 & $12,125 \pm 4,970$ & \\
\hline \multirow{2}{*}{$\begin{array}{l}\text { Test Straight Leg } \\
\text { (degree) Pretest }\end{array}$} & Treatment group & 8 & $68,438 \pm 6,936$ & \multirow{2}{*}{0,445} \\
\hline & Control group & 8 & $65,938+8,122$ & \\
\hline
\end{tabular}

*sign value from homogenity test with Anova test 
Based on the data in table 1 using the Anova test because the data is a ratio, it is known that the pvalue at age is 0.105; VAS Pretest of 0.348; RMDQ Pretest of 0.311; and the Straight Leg Pretest Test of
0.445. Because of the p-value of age, VAS, RMDQ, and the Straight Leg Test are more significant than 0.05; it can be concluded that the data distribution is normally distributed.

Table 2. Gender characteristics

\begin{tabular}{ccccc}
\hline & \multicolumn{2}{c}{ Gender } & \multirow{2}{*}{ Total } & p-value \\
\cline { 2 - 5 } & Male & Female & & \\
\hline Treatment group & 1 & 7 & 8 & 1,00 \\
\hline Control group & 1 & 7 & 16 & \\
\hline Total & 2 & &
\end{tabular}

Based on table 2 data using the Chi-square test because the data is categorical, it is known that the $\mathrm{p}$-value at age is 1.00 . Because the $\mathrm{p}$-value for gender is more significant than 0.05 , it can be concluded that the data distribution is normally distributed. The number of male and female research subjects in the two groups was uneven. The therapy group consisted of 1 male and nine female, while the control group consisted of 2 men and eight women.

In this study, out of a total of 20 subjects, 16 subjects followed the process until the end, and four others experienced drop out (two patients in each group). In the control group, one female study subject dropped out after following two therapies. Research subjects in control were declared to have dropped out because they could not fulfil a series of studies until the end as predetermined. At the same time, one other person in the control group was hospitalized due to a long history of mouth sores so that the patient could not eat and drink. In the therapy group, one female study subject dropped out after undergoing three therapies because the research subject was operated on in the hospital because before the study, the patient had heart disease, and one other person dropped out after undergoing eight therapies because they did not. can fulfil a series of studies to the end as determined. After being tested for normality with Kolmogorov-Smirnov as shown in the appendix, the VAS, RMDQ and Straight Leg Test data were obtained that were normally distributed ( $p$ $=>0.05)$.

Table 3. Normality test

\begin{tabular}{|c|c|c|c|c|c|c|c|}
\hline & & $\begin{array}{c}\text { VAS } \\
\text { Pretest }\end{array}$ & $\begin{array}{c}\text { VAS } \\
\text { Post test }\end{array}$ & $\begin{array}{l}\text { RMDQ } \\
\text { Pretest }\end{array}$ & $\begin{array}{c}\text { RMDQ } \\
\text { Post test }\end{array}$ & $\begin{array}{c}\text { Test } \\
\text { Straight Leg } \\
\text { pretest }\end{array}$ & $\begin{array}{l}\text { Test Straight } \\
\text { Leg post test }\end{array}$ \\
\hline \multirow{2}{*}{$\begin{array}{l}\text { Treatment } \\
\text { group }\end{array}$} & $\begin{array}{l}\text { Mean } \pm \\
\text { SD }\end{array}$ & $\begin{array}{c}5,125 \pm \\
1,246\end{array}$ & $\begin{array}{l}1,25 \pm \\
1,389\end{array}$ & $\begin{array}{c}13,625 \pm \\
3,461\end{array}$ & $\begin{array}{c}4,125 \pm \\
5,718\end{array}$ & $\begin{array}{c}68.437 \pm \\
6,935\end{array}$ & $\begin{array}{c}101.562 \pm \\
12,459\end{array}$ \\
\hline & p-value & 0.872 & 0.917 & 0.560 & 0.176 & 0.530 & 0.373 \\
\hline \multirow[t]{2}{*}{$\begin{array}{l}\text { Control } \\
\text { group }\end{array}$} & $\begin{array}{l}\text { Mean } \pm \\
\text { SD }\end{array}$ & $\begin{array}{c}5,625 \pm \\
1,847\end{array}$ & $\begin{array}{c}5,500 \pm \\
1,851\end{array}$ & $\begin{array}{r}12,125 \\
\pm 4,969\end{array}$ & $\begin{array}{c}11,625 \pm \\
3,583\end{array}$ & $\begin{array}{c}65,937 \pm \\
8,122\end{array}$ & $\begin{array}{c}70,937 \pm \\
5,660\end{array}$ \\
\hline & $p$-value & 0.734 & 0.611 & 0.386 & 0.583 & 0.893 & 0.933 \\
\hline
\end{tabular}

*p-value from normality test with kolmogorov smirnov 
Based on table 2 data using the Chi-square test because the data is categorical, it is known that the $\mathrm{p}$-value at age is 1.00. Because the $\mathrm{p}$-value for gender is more significant than 0.05, it can be concluded that the data distribution is normally distributed. The number of male and female research subjects in the two groups was uneven. The therapy group consisted of 1 male and nine female, while the control group consisted of 2 men and eight women.

In this study, out of a total of 20 subjects, 16 subjects followed the process until the end, and four others experienced drop out (two patients in each group). In the control group, one female study subject dropped out after following two therapies. Research subjects in control were declared to have dropped out because they could not fulfil a series of studies until the end as predetermined. At the same time, one other person in the control group was hospitalized due to a long history of mouth sores so that the patient could not eat and drink. In the therapy group, one female study subject dropped out after undergoing three therapies because the research subject was operated on in the hospital because before the study, the patient had heart disease, and one other person dropped out after undergoing eight therapies because they did not. can fulfil a series of studies to the end as determined. After being tested for normality with Kolmogorov-Smirnov as shown in the appendix, the VAS, RMDQ and Straight Leg Test data were obtained that were normally distributed $(\mathrm{p}$ $=>0.05)$.

Table 4. Normality test

\begin{tabular}{|c|c|c|c|c|c|}
\hline & & \multicolumn{4}{|c|}{ Paired Differences } \\
\hline & & & Mean & $\begin{array}{c}\text { Std. } \\
\text { Deviation }\end{array}$ & $\mathrm{p}$-value* \\
\hline \multirow{2}{*}{ VAS (mm) } & $\begin{array}{c}\text { Treatment } \\
\text { group }\end{array}$ & $\begin{array}{l}\text { Posttest- } \\
\text { pretest }\end{array}$ & $-3,875$ & 0,835 & 0,000 \\
\hline & $\begin{array}{l}\text { Control } \\
\text { group }\end{array}$ & $\begin{array}{c}\text { Post-test- } \\
\text { pre-test }\end{array}$ & $-0,125$ & 1,356 & 0,802 \\
\hline \multirow{2}{*}{$\begin{array}{c}\text { RMDQ } \\
\text { (questioner) }\end{array}$} & $\begin{array}{l}\text { Treatment } \\
\text { group }\end{array}$ & $\begin{array}{c}\text { Post-test- } \\
\text { pre-test }\end{array}$ & $-9,125$ & 6,010 & 0,002 \\
\hline & $\begin{array}{l}\text { Control } \\
\text { group }\end{array}$ & $\begin{array}{l}\text { Post-test- } \\
\text { pre-test }\end{array}$ & $-2,500$ & 5,657 & 0,598 \\
\hline \multirow{2}{*}{$\begin{array}{c}\text { Straight leg } \\
\text { test } \\
\text { (Derajat) }\end{array}$} & $\begin{array}{c}\text { Treatment } \\
\text { group }\end{array}$ & $\begin{array}{l}\text { Post-test- } \\
\text { pre-test }\end{array}$ & 32,188 & 14,5429 & 0,000 \\
\hline & $\begin{array}{l}\text { Control } \\
\text { group }\end{array}$ & $\begin{array}{l}\text { Post-test- } \\
\text { pre-test }\end{array}$ & 19,063 & 12,096 & 0,081 \\
\hline
\end{tabular}

* $p$ value was obtained from prepost T-test

Table 5. Unpaired T test on the posttest

\begin{tabular}{cccc}
\hline & Treatment group & Control group & $p$-value \\
& Mean $\pm \mathrm{SD}$ & Mean $\pm \mathrm{SD}$ & 0,000 \\
\hline VAS - posttest & $1,250 \pm 1,388$ & $5,500 \pm 1,852$ & 0,009 \\
RMDQ - posttest & $4,125 \pm 5,718$ & $11,625 \pm 3,583$ & 0,000 \\
Straight leg test - posttest & $101,563 \pm 12,460$ & $70,938 \pm 5,660$ & 0 \\
\hline
\end{tabular}

* sig value. (2-tailed) obtained by the unpaired T Test 
Based on table 5.5, it is known that the Sig. (2tailed) for a VAS of 0,000; RMDQ of 0.007; and a Straight Leg Test of 0,000 . The data is said to be significant if the Sig. (2-tailed) is less than 0.05. Thus, it can be concluded that the VAS, RMDQ, and Straight Leg Test are significant. Since all of them are significant, the values are based on the Equal Variances Assumed.

Table 6. Test prepost difference in the two groups

\begin{tabular}{cccc}
\hline & Treatment group & Control group & $p$-value \\
& Mean \pm SD & Mean \pm SD & 0,000 \\
VAS (mm) & $-3,875 \pm 0,835$ & $-0,125 \pm 1,356$ & 0,002 \\
RMDQ (Questionaire) & $-9,500 \pm 5,682$ & $-0,500 \pm 2,563$ & 0,000 \\
\hline
\end{tabular}

* sig value. (2-tailed) obtained by the unpaired T Test

Based on table 5.6, it is known that the Sig. (2tailed) for a VAS of 0,000; RMDQ of 0.001; and a Straight Leg Test of 0,000 . The data is said to be significant if the Sig. (2-tailed) is less than 0.05. Thus, it can be concluded that the VAS, RMDQ, and Straight Leg Test on the Pretest Posttest Unpaired TTest are significant. Because everything is significant, the values are based on the Equal Variances Assumed.

From the results of statistical tests showed a decrease in pain between before and after giving acupressure therapy. Thus, it can be concluded that acupressure can help reduce LBP pain according to previous studies. Research that has been conducted at the University of Chulalongkorn obtained data, that acupressure can improve body condition better and reduce LBP pain by stimulating Shenshu acupoints (BL23) and Dachangshu points (BL25). In another journal, it was stated that acupressure could reduce the level of acute and chronic pain so that it can reduce pharmacological drugs that have side effects.

Conventionally the acupressure mechanism that occurs in the therapy group with Dachangshu points (BL25), Shenshu points (BL23) and Yaoyangguan points (DU3) is the analgesic effect that occurs in acupressure activities using acupuncture points, which involves the pain reduction system of the body itself. With the release of endorphins, serotonin, norepinephrine or $\gamma$-aminobutyric acid. 10 Endorphin hormones are compounds released in the lower back of the brain, which function to make people feel comfortable and happy so that the pain they suffer can be reduced.

The stimulation caused by pressing the acupressure point in this study is the same as the stimulation using a needle pricking the acupuncture point. So that the mechanism that occurs is the same, the mechanism that occurs when stimulated is a stimulating type I and type II afferent nerves or delta fibres in the muscles which send impulses to the anterolateral tract in the spinal cord. Pain is inhibited presynaptically by the release of enkephalin and dynorphins, preventing pain messages from ascending the spinothalamic tract. Stimulation of the pituitary hypothalamic complex causes the systemic release of beta-endorphins into the bloodstream from the pituitary gland. The release of adrenocorticotropic hormones accompanies the release of betaendorphins. ${ }^{11,12}$

Shenshu point (BL23), Dachangshu point (BL25) and Yaoyangguan point (DU3) can be used to reduce pain in LBP. The journal entitled Acupuncture For Chronic Low Back Pain In Older Patients: A 
Randomized, Controlled Trial in 2003 stated that Yaoyangguan point (DU3), Dachangshu point (BL25) and Shenshu point (BL23) effectively reduce LBP pain on acupuncture.

Shenshu point (BL23), Dachangshu point (BL25) and Yaoyangguan point (DU3) are located on the lumbar bone, and the exact location of LBP pain is felt. Another study suggests that local analgesic acupuncture can stimulate $A \beta$-type sensory fibres derived from peripheral tactile receptors, which can suppress the transmission of pain signals from the same area of the body. Dachangshu point (BL25) is the Shu point the large intestine meridian located in the lumbar area. Another study using mice explained that Dachangshu point stimulation could reduce P2X7 mRNA and glial fibrillary acidic protein (GFAP) upregulated in the dorsal root ganglia (DRG). Thus, inhibiting the transmission of nociceptive receptors which can induce visceral pain. ${ }^{13}$

Shenshu point (BL23) is the Shu point of the bladder meridian located in the lumbar area. Shenshu Point is also indicated to smooth the movement of Qi and blood and activate the collateral area, thereby reducing pain in LBP.

The yaoyangguan point (DU3) is a privileged point located on the posterior midline and the fourth lumbar bone. A study using rats suggested that stimulation of the Yaoyangguan point and the Shenshu point reduced pain by significantly lowering the serum TNF-a and IL-1 $\beta$ levels. So that it can help reduce inflammation caused by the serum. The use of Shenshu point together with Dachangshu and Weizhong is reported to have a synergistic effect on reducing LBP pain. ${ }^{14}$

Traditionally, LBP disease can be caused by external trauma, or internal deficiencies in the body's resistance and the entry of PPL pathogens in cold or cold winds, resulting in blockage of qi and blood on the meridians which is the cause of pain in the lumbar region. Other factors that cause LBP such as cold winds and damp pathogens that attack the body into the organs and sufferers feel pain in the lower back area. Blood stasis that occurs due to weak Qi and pathogens attack, so that blood circulation is not smooth and ends up in the blood stasis, as well as renal jing deficiency which is usually caused by weakness or illness, age factors or excessive sexual activity that disturbs the kidneys causing low back pain. 15

Shenshu point (BL23) is the Shu point (current) in the kidney organ. This point is a useful point commonly used to reduce pain in the lower back. This kidney point also affects the direct stimulation of the kidney because it is located in the lower back. Besides, stimulation at this point reduces pain in the LBP. 1,16

The Dachangshu point (BL25) is the Shu point in the small intestine. This point affects the small intestine and is located on the lower back. In addition, according to research conducted by the University of Maryland in 2003, it was shown that at the Shenshu point (BL23), Qihaishu point (BL24), Dachangshu point (BL25) and Pangguangshu point (BL28) using acupuncture experienced an improvement in pain in LBP .

Previous research has used acupuncture techniques, so the researchers wanted to observe the effect of using acupressure methods. Shenshu point (BL23), Dachangshu point (BL25) and Yaoyangguan point (DU3) influence this study which is evident in the results of decreasing VAS, RMDQ and Straight Leg Test scores. ${ }^{17,18}$ There is a hypothesis that acupressure therapy is related to the central nervous system. However, to prove it needs further research.

Acupressure therapy effectively influences the therapeutic process. The use of acupressure therapy is more comfortable and safer for patients who follow the research on acupressure therapy that can also be applied in the community. The control group using no indication of pain showed no change in VAS, RMDQ and Straight Leg Test scores. The points used in the control group were Dingchuan points (EXB1) 
and Waihuaijian points (EX-LE10). Indications at Dingchuan point (EX-B01) are cough, bronchitis, and asthma. In comparison, the indication at the Waihuaijian point (EX-LE10) is used for eczema, rubella, pyogenic infections in the feet. This study has limitations on the measurement of RMDQ; the research subjects were only carried out at the time before (pretest), and at the end of the whole series of therapy processes (posttest). In future, it is necessary to carry out further research to determine the relationship between the Shenshu point, Dachangshu point, and Yaoyangguan point with changes in the anatomical condition of the tongue of the research subject. The diagnosis of the tongue is one aspect of the diagnosis of TCM. Besides, it is necessary to observe the daily lives of the research subjects by filling in the diagnosis using TCM.

\section{Conclusion}

Acupressure therapy at Shenshu point (BL23), Dachangshu point (BL25) and Yaoyangguan duck (DU3) were effective in reducing the pain threshold in cases of low back pain.

\section{References}

1. Ningrum plu. Pengaruh akupunktur titik shenshu (bl 23), weizhong (bl 40), yaoyangguan (du 03) terhadap penurunan ambang rasa nyeri low back pain pada perempuan usia 17-25 tahun. 2016.

2. Ardiyana AK, Kurniawati D, Ft Ss. Pengaruh Latihan Combination Of Isotonic (COI) Dan Edukasi Terhadap Pengurangan Nyeri Punggung Bawah (NPB) Pada Pekerja Laundry Di Desa Pabelan. 2016.

3. Samara D, Sulistio J, Rachmawati MR, Harrianto R. Sikap membungkuk dan memutar selama bekerja sebagai faktor risiko nyeri punggung bawah. Universa Med. 2005; 24(3): 132-133.
4. Septadina IS, Adnindya MR, Suciati T. A radiologic feature of spine related to musculoskeletal disorder on pedicab drivers. In: Journal of Physics: Conference Series. Vol 1246. IOP Publishing; 2019;12058.

5. Walsh K, Cruddas M, Coggon D. Low back pain in eight areas of Britain. J Epidemiol Community Heal. 1992; 46(3): 227-230.

6. Anggraeni RR. Manfaat peregangan otot terhadap keluhan nyeri punggung bawah pada pekerja bagian knitting gantung PT. Royal Korindah Purbalingga. 2015.

7. Maulana W. Perilaku Kesehatan Pasien Ketika Berobat Ke Pengobatan Alternatif Atfg-8 Cabang Surakarta. 2011.

8. Handayani N, Khairiyatul RKA. Pengaruh Akupresur Terhadap Penurunan Mual Dan Muntah Pada Ibu Hamil Di Praktek Mandiri Bidan Sidoarjo. Embrio. 2019; 11(2): 102109.

9. Ganglin Y, Zhenhua L. Advanced Modern Chinese Acupuncture Therapy. 2000.

10. Aswitami GAP, Mastiningsih P. Pengaruh Terapi Akupresur terhadap Nyeri Punggung Bawah pada Ibu Hamil TM III di Wilayah Kerja Puskesmas Abian Semal 1. Str J Ilm Kesehat. 2018; 7(2): 47-51.

11. HIDAYAH B. Penanganan Gastritis Menggunakan Kombinasi Terapi Akupunktur Pada Titik Zusanli (St36), Neiguan (Pc6), Neiting (St 44) Dengan Herbal Kunyit (Curcuma Domestica Val.). 2017.

12. Retno Asih D. Perbandingan Efektivitas Antara Teknik Akupresur dengan Pelvic Rocking dalam Mempercepat Proses Persalinan Kala I di Praktik Mandiri Bidan (PMB) Wilayah Kecamatan Metro Barat. 2019.

13. Tamus AY, Boesoirie MTS, Aroeman NA. Korelasi Antara Visual Analogue Scale (VAS) 
dan Peak Nasal Inspiratory Flow (PNIF)

Sebelum dan Sesudah Septoplasti. Maj

Kedokt Bandung. 2015; 47(3): 186-191.

14. Kurniyawan EH. Narrative Review: Terapi Komplementer Alternatif Akupresur Dalam Menurunkan Tingkat Nyeri.

15. Jimenez SLM. Acupressure: Pain relief at your fingertips. Int J Childbirth Educ. 1995; 10(4): 7-10.

16. Fassoulaki A, Paraskeva A, Kostopanagiotou G, Tsakalozou E, Markantonis S. Acupressure on the extra 1 acupoint: the effect on bispectral index, serum melatonin, plasma $\beta$-endorphin, and stress. Anesth Analg. 2007; 104(2): 312-317.

17. Chien L-W, Chen F-C, Hu H-Y, Liu C-F. Correlation of electrical conductance in meridian and autonomic nervous activity after auricular acupressure in middle-aged women. J Altern Complement Med. 2014; 20(8): 635-641.

18. Aszar FDD, Imandiri A, Mustika A. Therapy for Low Back Pain with Acupuncture and Turmeric. J Vocat Heal Stud. 2018; 2(2): 7479. 